\title{
Review
}

\section{Recent advances in understanding Antarctic climate evolution}

\section{MARTIN J. SIEGERT ${ }^{1 *}$, PETER BARRETT ${ }^{2}$, ROBERT DECONTO ${ }^{3}$, ROBERT DUNBAR ${ }^{4}$, COLM Ó COFAIGH ${ }^{5}$, SANDRA PASSCHIER ${ }^{6}$ and TIM NAISH ${ }^{2,7}$}

\author{
${ }^{1}$ School of GeoSciences, University of Edinburgh, Grant Institute, Edinburgh EH9 3JW, UK \\ ${ }^{2}$ Antarctic Research Centre, Victoria University of Wellington, PO Box 600, Wellington, New Zealand \\ ${ }^{3}$ Department of Geosciences, 611 North Pleasant Street, 233 Morrill Science Center, University of Massachusetts, Amherst, \\ MA 01003-9297, USA \\ ${ }^{4}$ Department of Geological and Environmental Sciences, 325 Braun Hall (bldg. 320), Stanford University, Stanford, CA 94305-2115, USA \\ ${ }^{5}$ Department of Geography, Durham University, Science Site, South Road, Durham DH1 $3 L E, U K$ \\ ${ }^{6}$ Department of Earth and Environmental Studies, Mallory Hall 252, Montclair State University, Montclair, NJ 07043, USA \\ ${ }^{7}$ Institute of Geological and Nuclear Sciences, PO Box 30368, Lower Hutt, New Zealand \\ *m.j.siegert@ed.ac.uk
}

\begin{abstract}
Geological evidence shows that the ice sheet and climate in Antarctica has changed considerably since the onset of glaciation around 34 million years ago. By analysing this evidence, important information concerning processes responsible for ice sheet growth and decay can be determined, which is vital for appreciating future changes in Antarctica. Geological records are diverse and their analyses require a variety of techniques. They are, however, essential for the establishment of hypotheses regarding past Antarctic changes. Numerical models of ice and climate are useful for testing such hypotheses, and in recent years there have been several advances in our knowledge relating to ice sheet history gained from these tests. This paper documents five case studies, employing a full range of techniques, to exemplify recent insights into Antarctic climate evolution from modelling ice sheet inception in the earliest Oligocene to quantifying Neogene ice sheet fluctuations and process-led investigations of recent (last glacial) changes.
\end{abstract}

Received 15 January 2007, accepted 29 August 2007

Key words: Cenozoic, environment, glacial history, ice sheet

\section{Introduction}

Large ice sheets have existed on Antarctica since at least earliest Oligocene times (Wise et al. 1991, Barrett 1996), approximately 34 million years ago. Since then it has fluctuated considerably and has been one of the major driving forces for changes in global sea level and climate. The size and timing of these fluctuations has been the subject of considerable debate. Knowing how large ice masses and associated sea ice respond to external forcing is of vital importance, because ice volume variations change 1) global sea level on a scale of tens of metres or more, and 2) the capacity of ice sheets and sea ice as major heat sinks, insulators and reflectors. It is thus important to assess the stability of the cryosphere under a warming climate and higher atmospheric $\mathrm{CO}_{2}$ levels (IPCC 2001) when ice volumes may reduce, particularly as ice core records have yielded evidence of a strong correlation between $\mathrm{CO}_{2}$ in the atmosphere and palaeotemperatures (EPICA 2004). This concern is justified when $\mathrm{CO}_{2}$ levels are compared with temperature changes in the more distant past (Crowley \& Kim 1995, Pagani et al. 2005). For example, IPCC (2001) estimated global mean temperatures in 2300 , from 'best case' projections of atmospheric $\mathrm{CO}_{2}$, that have not occurred on Earth for over $50 \mathrm{Ma}$. Since variation in Antarctic ice volume is a major driver of Earth's climate and sea level, much effort has been expended in deriving numerical models of its behaviour. Some of these models have been successfully evaluated against modern conditions (Le Broqc 2007). Employing numerical models to evaluate past ice sheet behaviour, using the record of changes in climate (inferred from ice cores, sedimentary facies, and seismic data), palaeoceanographic conditions (inferred from palaeoecology and climate proxies in ocean sediments) and palaeogeography (as recorded in landscape evolution), provides a powerful means by which quantitative process-led assessments of the cryosphere's involvement in a variety of climate change episodes can be established. Such assessment is critical to predicting how the Antarctic Ice Sheet will respond to, and force, future environmental changes.

Recognizing the importance of understanding past changes in Antarctica to comprehending future changes, the Scientific Committee on Antarctic Research has developed a programme, entitled ACE (Antarctic Climate evolution), aimed at facilitating research in the broad area of Antarctic glacial and climate history. In this review we assess five areas of activity in which the ACE programme has been focused. These five examples are not meant to be an exhaustive account of research undertaken on Antarctic 


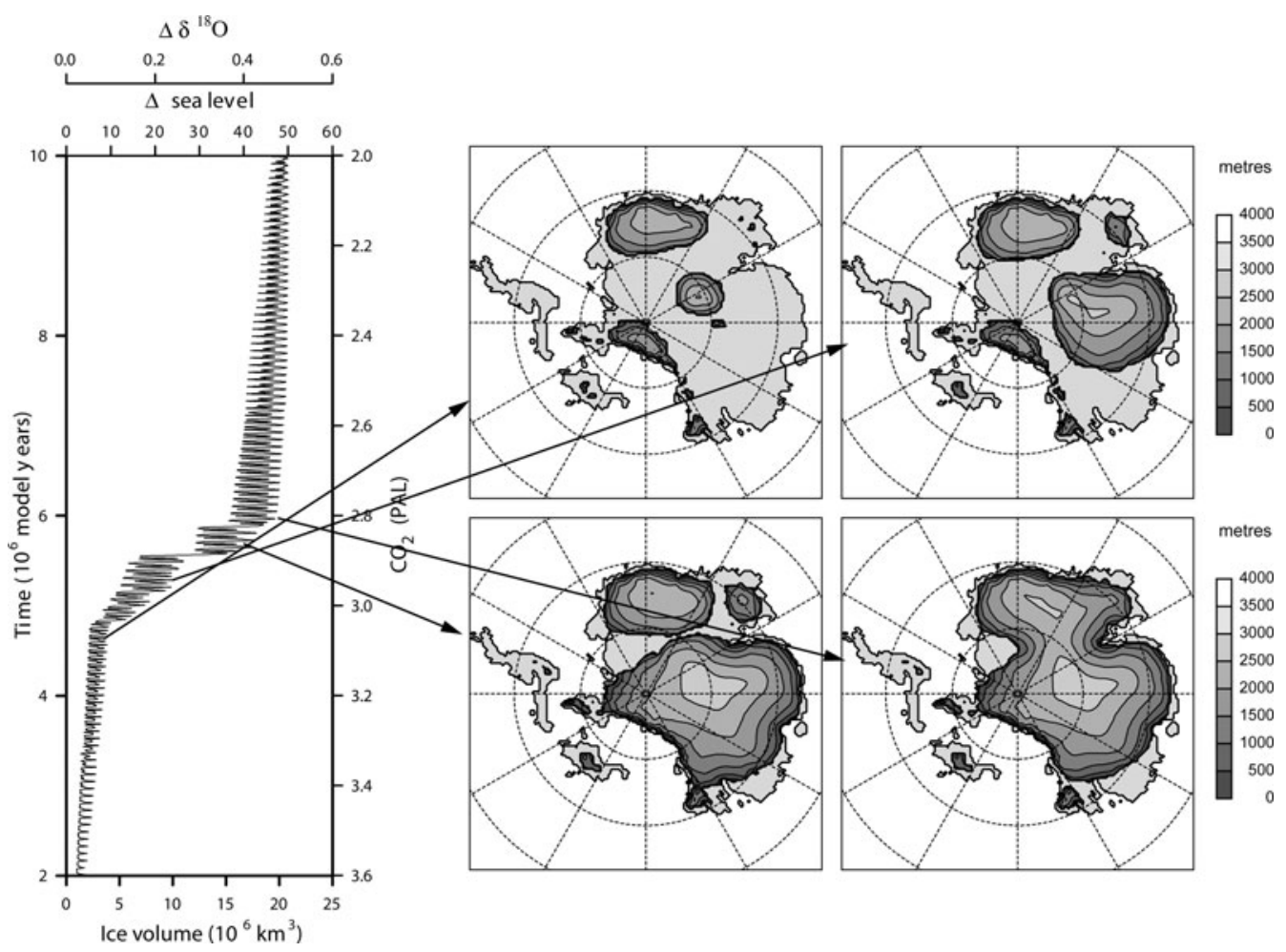

Fig. 1. Ice volume (left) and corresponding ice sheet geometries (right) simulated by a coupled GCM ice sheet model in response to a slow decline in atmospheric $\mathrm{CO}_{2}$ and idealized orbital cyclicity across the Eocene-Oligocene boundary. The sudden, two-step jump in ice volume (left panel) corresponds to the Oi-1 event. The left panel shows simulated ice volume, extrapolated to an equivalent change in sea level and the mean isotopic composition of the ocean (top). Arbitrary model years (left axis) and corresponding, prescribed atmospheric $\mathrm{CO}_{2}$ (right axis) are also labelled. Atmospheric $\mathrm{CO}_{2}$ is shown as the multiplicative of pre-industrial (280 ppmv) levels. Ice sheet geometries (right panels) show ice sheet thickness in metres. Black arrows correlate simulated ice volumes with the geometric evolution of the ice sheet through the Oi-1 event (modified from DeConto \& Pollard 2003b).

climate evolution, but they do provide a means of gauging the variety of activities needed to gain a fuller appreciation of Antarctic glacial history. The review begins with a discussion concerning the onset of glaciation in Antarctica in the earliest Oligocene, with subsequent assessment of ice sheet fluctuations during the Neogene. The review continues with an account of ice sheet changes following the last glacial maximum, and ends with an example for how geological evidence can be used to characterise modern ice sheet processes.

\section{Connection of $\mathrm{CO}_{2}$ and ice sheet inception at the Eocene-Oligocene boundary}

Whereas the onset of major, continental-scale glaciation in the earliest Oligocene (Oi-1 event) has long been attributed to the opening of Southern Ocean gateways (Kennett \& Shackleton 1976, Kennett 1977, Exon et al. 2002), recent numerical modelling studies suggest declining atmospheric $\mathrm{CO}_{2}$ was the most important factor in Antarctic cooling and glaciation.

As the passages between South America and the Antarctic Peninsula (Drake Passage), and Australia and East Antarctica
(Tasmanian Passage) widened and deepened during the late Palaeogene and early Neogene (Lawver \& Gahagan 1998), strengthening of the Antarctic Circumpolar Current and Polar Frontal Zone were thought to have cooled the Southern Ocean by limiting the advection of warm subtropical surface waters into high latitudes (Kennett 1977). A number of ocean modelling studies have indeed shown that the opening of both the Drake and Tasmanian gateways reduces poleward heat convergence in the Southern Ocean, cooling sea surface temperatures by several degrees (Mikolajewicz et al. 1993, Nong et al. 2000, Toggweiler \& Bjornsson 2000).

Whereas the opening of the Tasmanian gateway broadly coincides with the earliest Oligocene glaciation event (Oi-1) (Stickley et al. 2004), the tectonic history of the Scotia Sea remains equivocal. Estimates for the opening of Drake Passage range between 40 and $20 \mathrm{Ma}$ (Barker \& Burrell 1977, Livermore et al. 2004, Scher \& Martin 2006), blurring the direct 'cause and effect' relationship between the gateways and glaciation. Furthermore, recent atmosphere-ocean modelling (Huber et al. 2004) has shown that the Tasmanian Gateway probably had a minimal effect on oceanic heat convergence and sea surface temperatures around the continent, because the warm East Australia Current does 
not travel any further south if the gateway is open or closed. The gateway's effect on East Antarctic climate and snowfall was also shown to be minimal, pointing to some other forcing (perhaps decreasing atmospheric $\mathrm{CO}_{2}$ concentrations) as the primary cause of Antarctic cooling and glaciation.

One aspect of recent modelling has focused on the development of coupled climate-ice sheet models capable of running long ( $>10^{6} \mathrm{yr}$ ), time-continuous simulations of specific climate events and transitions (DeConto \& Pollard 2003a). Simulations spanning the Eocene-Oligocene boundary while accounting for decreasing $\mathrm{CO}_{2}$ concentrations and orbital variability (DeConto \& Pollard 2003b, Pollard \& DeConto 2005), have led to the conclusions that 1) tectonically-forced changes in ocean circulation and heat transport have only a small effect on temperature and glacial mass balance in the Antarctic interior and (2) Southern Ocean gateways could only have triggered glaciation if the climate system was already near a threshold. Considering the sensitivity of polar climate to the range of $\mathrm{CO}_{2}$ concentrations likely to have existed over the Palaeogene-Neogene (Pagani et al. 2005), $\mathrm{CO}_{2}$ probably played a fundamental role in controlling Antarctica's climatic and glacial sensitivity to a wide range of forcings. This conclusion is supported by a number of numerical modelling studies exploring the role of orbital variability (DeConto \& Pollard 2003b), mountain uplift in the continental interior (DeConto \& Pollard 2003a), geothermal heat flux (Pollard et al. 2005), Antarctic vegetation dynamics (Thorn \& DeConto 2006), and Southern Ocean sea ice (DeConto et al. 2007) in the Eocene-Oligocene climatic transition.

The results of these studies can be summarized as follows. The timing of glaciation on East Antarctica was shown to be sensitive to orbital forcing, mountain uplift, and continental vegetation, but only within a very narrow range of atmospheric $\mathrm{CO}_{2}$ concentrations around 2.8 times preindustrial level - close to the model's glaciation threshold. Once the glaciation threshold is approached, astronomical forcing can trigger sudden glaciation through non-linear height/mass-balance and albedo feedbacks that result in the growth of a continental-scale ice sheet within $100 \mathrm{kyr}$ (Fig. 1). The timing of glaciation appears to be insensitive to both expanding concentrations of seasonal sea ice and changes in geothermal heat flux under the continent. However, a doubling of the background geothermal heat flux (from 40 to $80 \mathrm{~mW} \mathrm{~m}^{-2}$ ) does have a significant effect on the area under the ice sheet at the pressure meltpoint (where liquid water is present), which may have had some influence on the distribution and development of subglacial lakes (Siegert \& Dowdeswell 1996, Siegert et al. 2005).

Whereas these modelling studies have certainly improved our understanding of the importance of atmospheric $\mathrm{CO}_{2}$ concentrations relative to other Cenozoic forcing factors,

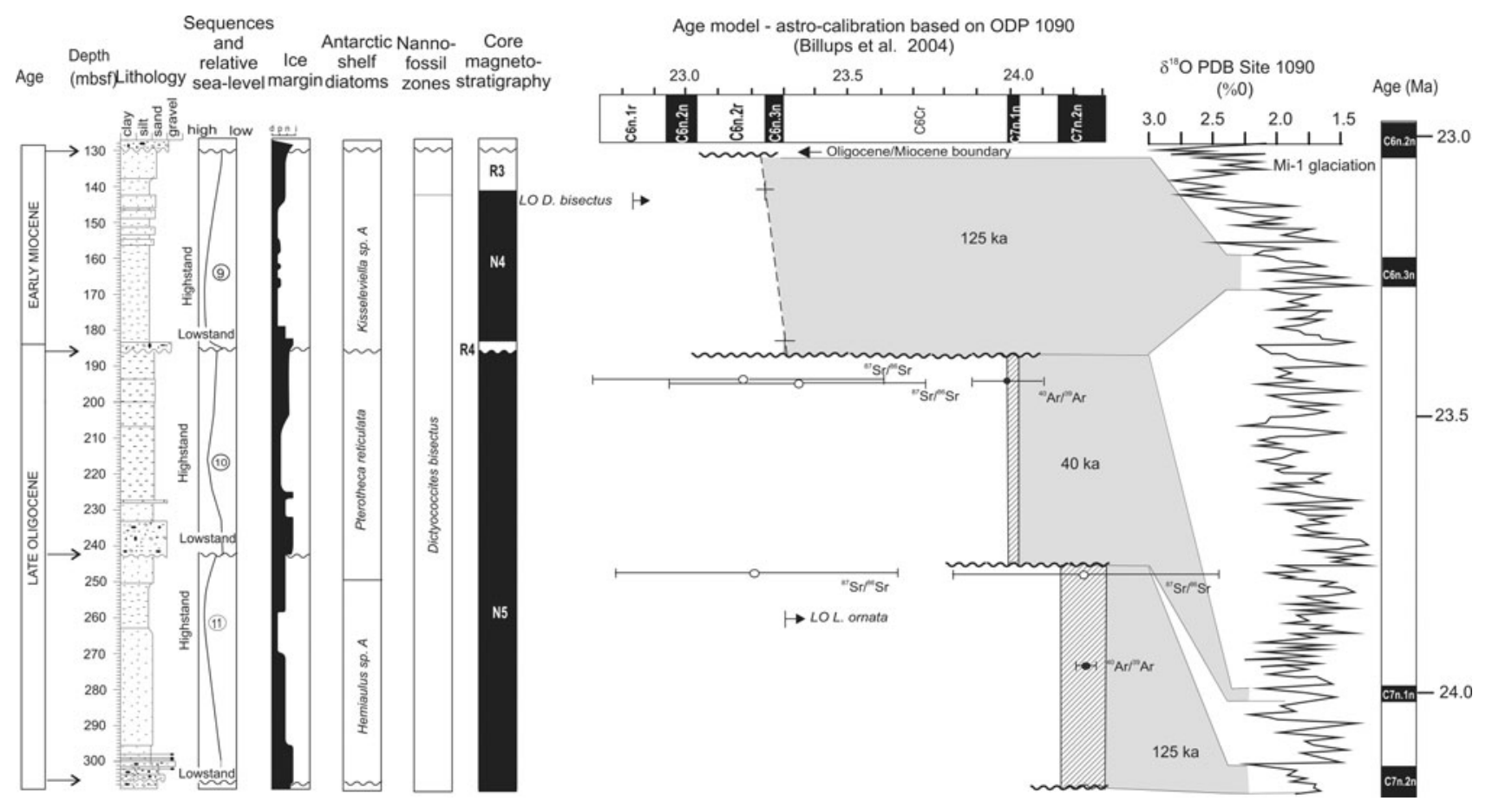

Fig. 2. Revised age model for Late Oligocene glacimarine cycles 9, 10 and 11 from CRP2/2A showing correlations to the high-resolution ODP Site $1090 \delta^{18} \mathrm{O}$ record. $40^{\mathrm{Ar}} / 39^{\mathrm{Ar}}$ ages on tephra allows cycles 11 and 10 to be correlated with individual Milankovitch-scale, glacial-interglacial cycles within polarity chrons C7n2n and C7n1n, respectively. Cycle 9 is correlated with C6n3n. The Mi-1 glaciation and the Oligocene-Miocene boundary correspond to the 3Ma-duration unconformity at the top of Cycle 9. 
several important model-data inconsistencies remain unresolved. For example, long, time-continuous GCM-ice sheet simulations of an increasing $\mathrm{CO}_{2}$ (warming) scenario, show strong hysteresis once a continental ice sheet has formed, in which the ice surface elevation reaches a maximum where ice accumulation rates are low and subsequently lowers under increasing surface accumulation, which leads to ice build-up (Pollard \& DeConto 2005). In these simulations, orbital forcing alone is not sufficient to produce the range of Palaeogene-Neogene ice sheet variability ( $\sim 50-120 \%$ of modern Antarctic ice volumes) inferred from marine oxygen isotope records and sequence stratigraphic reconstructions of eustasy (Zachos et al. 1992, Pekar \& DeConto 2006, Pekar et al. 2006). This points to the importance of additional feedbacks (possibly related to the marine carbon cycle, atmospheric $\mathrm{CO}_{2}$ or even nonlinear internal ice sheet processes) in controlling Cenozoic ice sheet variability.

Several recent isotopic analyses of deep sea cores imply ice volumes during the peak Oligocene and Miocene glacial intervals that are too big to be accommodated by East Antarctica alone (Coxall et al. 2005, Holbourn et al. 2005, Lear et al. 2004). Furthermore new isotopic analyses of deep sea sediments of Eocene age are now being taken to imply periods of significant ice cover in both Polar Regions (Tripati et al. 2005). These observations suggest that either our interpretations of the proxy data are faulty, or episodic, bipolar glaciation occurred much earlier than currently accepted (Eldrett et al. 2007). These, among other unresolved controversies related to the climatic and glacial evolution of the high southern latitudes will be the focus of future modelling and model-data comparisons.

\section{Orbital control on East Antarctic ice sheet dynamics across the Oligocene-Miocene boundary}

Orbital control of Northern Hemisphere ice sheet volume in the Quaternary ice ages has been well established for a quarter of a century (e.g. Mix \& Ruddiman 1984, Shackleton et al. 1984, Ruddiman et al. 1989, Maslin et al. 1999). Now, through drilling off the Antarctic margin at Cape Roberts it has been shown for the Antarctic Ice Sheet for the period from 33 to 17 million years ago. Around $1500 \mathrm{~m}$ of strata in this age range were cored and 55 sedimentary cycles identified, ranging from a few metres to over $60 \mathrm{~m}$ in thickness (Naish et al. 2001a). The cyclic variation in lithology records both advance and retreat of the ice margin and the fall and rise of sea level. Two latest Oligocene cycles preserve volcanic ash layers whose ages link them with particular Milankovitch cycles around 24.0 and 24.2 million years ago in the deep sea isotope record (Zachos et al. 1997, Naish et al. 2001b) (see Fig. 2). While calibration of the ice volume component of deep sea isotope records (Pekar et al. 2006, Pekar \& DeConto 2006) indicates orbital-duration eustatic sea level variations of $10-40 \mathrm{~m}$ at this time, it had hitherto not been possible to evaluate these inferred changes from direct evidence for coeval oscillations of sea level and changes in the volume of the Antarctic ice sheets. Naish et al. (in press) used a grain size-derived palaeobathymetry curve (Dunbar et al.

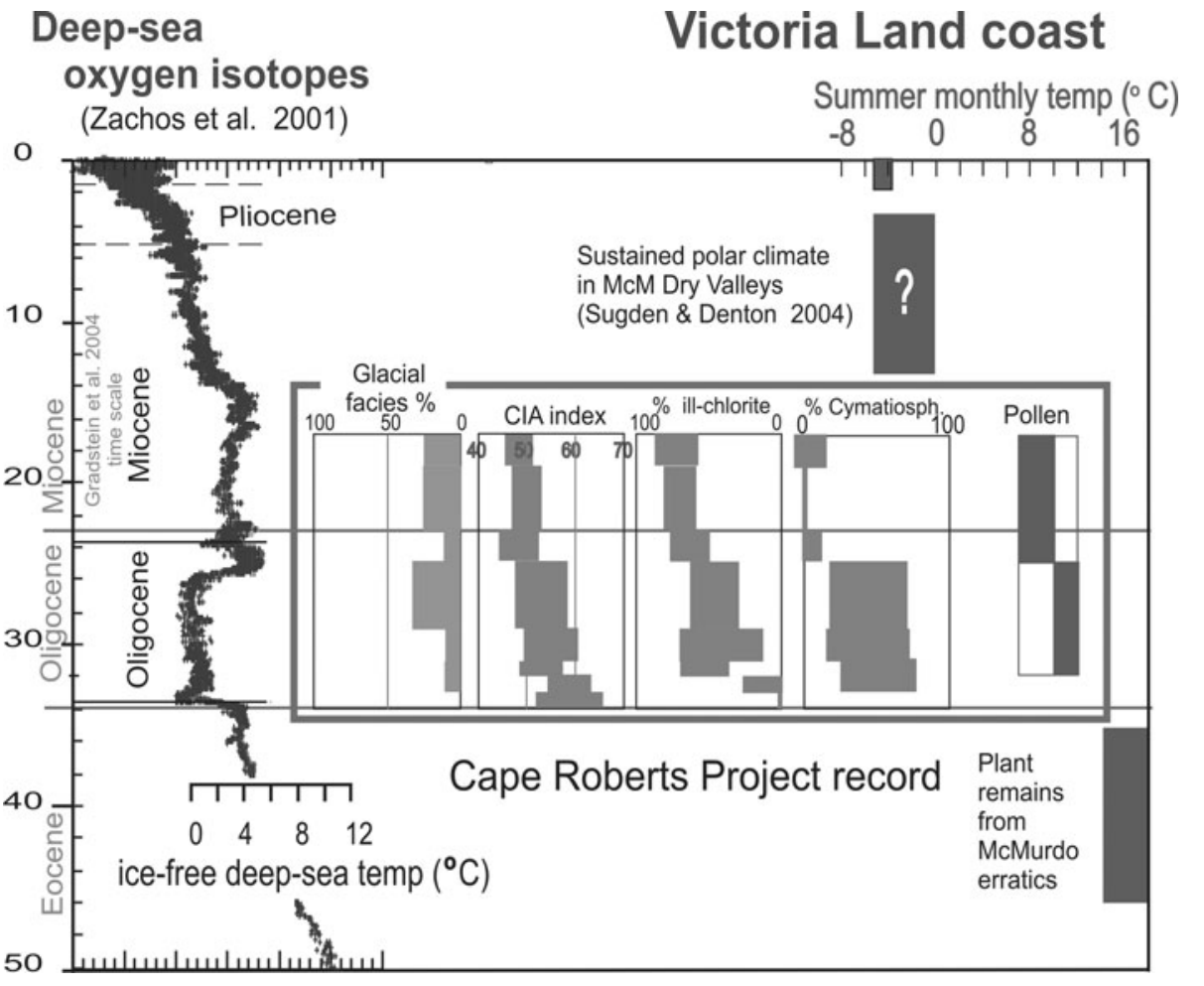

Fig. 3. Trends in climate proxies from the Cape Roberts section for the period from 34-17 Ma, compared with the composite deep-sea oxygen isotope curve of Zachos et al. (2001). The temperature estimates on the right are for interglacial periods and for mean summer monthly (December, January, February) temperature. For the last two million years it is based on the temperature records from Scott Base, Ross Island, since 1957 (-5 $\mathrm{C})$. See Barrett (in press) for further explanation. 386 387 388 393 394 395 396 397 398 399 400 401 402 403 404 405 406 407 408 409 410 411 412 413 414 415 


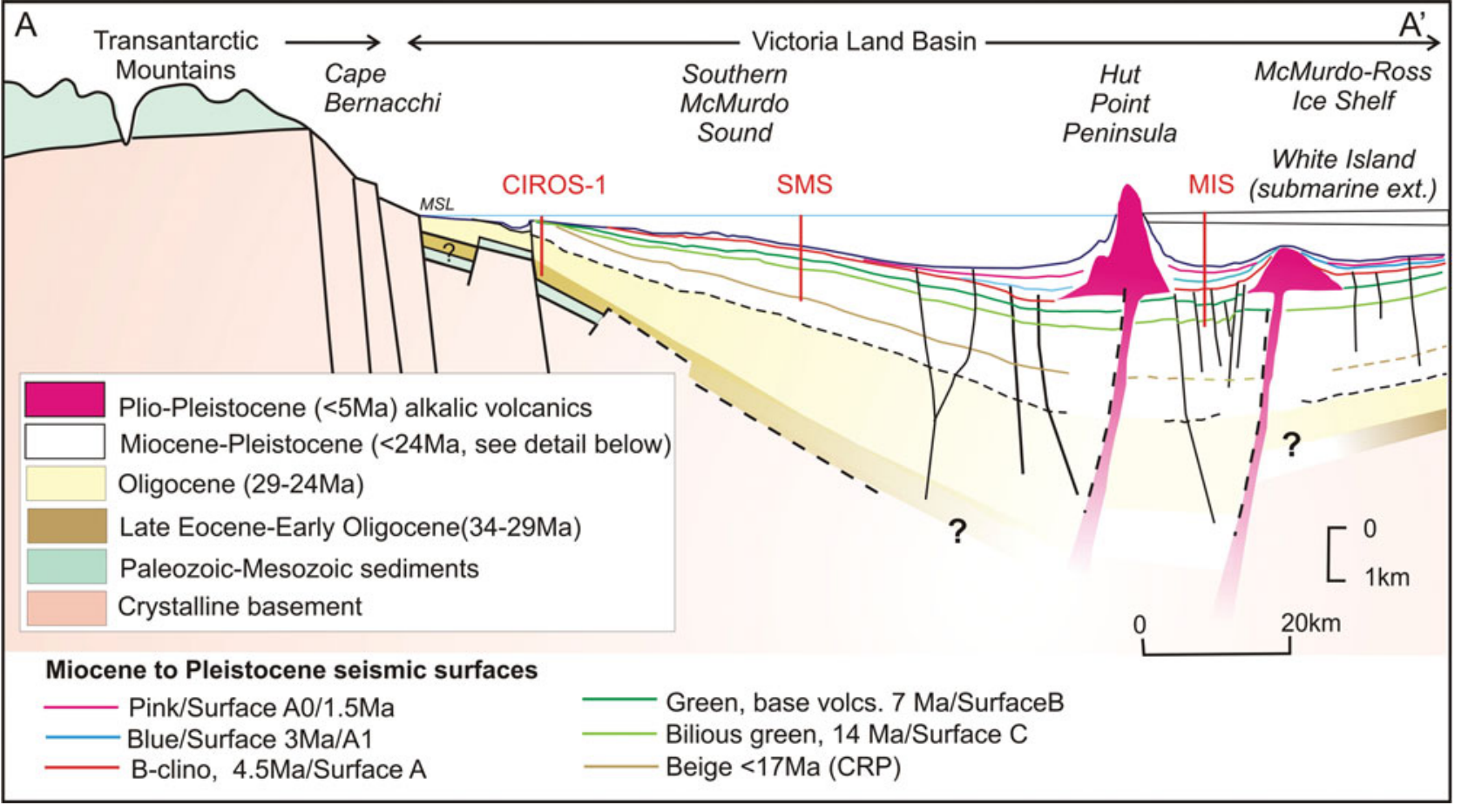

Fig. 4. Geological cross-section of McMurdo Sound from seismic stratigraphy and drill hole data (Naish et al., 2006).

in press), to determine the amplitude of eustatic sea level fluctuations, represented by glacimarine cycles in the Cape Roberts core. Their approach estimated the eustatic sea level contribution to the palaeobathymetry curve by using a simple back-stripping approach to constrain total subsidence, decompacted sediment accumulation and glacio-isostasy. The resulting eustatic estimates were consistent with the Late Oligocene $\delta^{18} \mathrm{O}$ to sea level calibrations of Pekar et al. (2006), and show that eustatic sea level fluctuated between around 10 and $40 \mathrm{~m}$, and represented ice volume fluctuations involving $15 \%$ to $60 \%$ of the present day Antarctic Ice Sheet. This work also implies a $\delta^{18} \mathrm{O}$ calibration for the Mi-1 glacial excursion that supports a significant expansion of ice on Antarctica, perhaps equivalent to $120 \%$ of the present day East Antarctic Ice Sheet, with an attendant fall in global sea level of $\sim 50 \mathrm{~m}$.

A further conclusion from the Cape Roberts record is that coastal temperature declined progressively through Oligocene and early Miocene time (Barrett 2006, Fig. 3). This is at odds with the initial interpretation of the Zachos et al. (2001) synthesis of the Cenozoic oxygen isotopic record, where a major shift of the $\delta^{18} \mathrm{O}$ values at $\sim 25 \mathrm{Ma}$ was interpreted as a warming of the oceans. This has been found to result from splicing records from high and low latitudes (and cold to warm water masses, Pekar et al. 2006). A revised global Cenozoic proxy temperature record is now overdue.

The ANDRILL Program has successfully recovered a $1285 \mathrm{~m}$ long succession of cyclic glacimarine sediment with inter-bedded volcanic deposits from beneath the
McMurdo Ice Shelf (MIS, forms the north-west corner of the Ross Ice Shelf). The MIS drillcore represents the longest and most complete $(98 \%$ recovery) geological record from the Antarctic continental margin to date, and will provide a key reference record of climate and ice sheet variability through the Late Neogene (Naish et al. 2007). Drilling in Southern McMurdo Sound in late 2007 aims to extend the record back to 20 million years (Harwood et al. 2006). Together, the Cape Roberts and ANDRILL cores will provide an unprecedented palaeoenvironmental record for this part of the Antarctic margin for the last 34 million years through $3500 \mathrm{~m}$ of strata (Fig. 4).

\section{Neogene major advance and retreat episodes of the East Antarctic Ice Sheet}

In the 1980s, studies of the Sirius Group and geomorphological investigations in the Transantarctic Mountains led to the development of 'dynamic' versus 'stable' ice sheet hypotheses, representing widely contrasting views of Neogene Antarctic climate and glacial dynamics (Webb et al. 1984, Denton et al. 1984). While comprehensive studies of landscape evolution in the McMurdo Sound region support a persistent ice sheet in central East Antarctica through Neogene time (Sugden \& Denton 2004), preserved fragments of a pre-mid Miocene landscape carved by temperate ice have been recognized (Hicock et al. 2003) and the extreme relief of the Transantarctic Mountains has been linked to continued 23 524 525 526 527 528 529 530 531 532 533 539 540
541 541
542 542
543 543
544 544
545 545
546 546
547 548 548
549 549
550 
erosion in the valley floors while the summit tops remained frozen (Stern et al. 2005). Based on compositional studies of the glacigenic sedimentary rocks themselves, Passchier (2001, 2004) concluded that the Sirius Group could have been deposited concurrently with stepwise glacial denudation of the Transantarctic Mountains.

Nevertheless, recent drilling by the Ocean Drilling Program in Prydz Bay, field studies of the Pagodroma Group exposed on land, and numerical modelling studies, provide evidence for a more complex behaviour of the Neogene East Antarctic Ice Sheet. The importance of large outlet glaciers as major drainage pathways of the East Antarctic Ice Sheet is apparent in RADARSAT data (Jezek 2003) and from the presence of Neogene trough mouth fans, represented by sediment wedges on the continental slopes seaward of large glacial troughs (O'Brien \& Harris 1996, Bart et al. 1999, 2000).

The Lambert Glacier is the largest fast flowing outlet glacier in the world and drains c. $12 \%$ of the East Antarctic Ice Sheet into Prydz Bay. During advances of the Lambert Glacier to the shelf break, glacigenic debris flows built up a trough mouth fan on the continental slope. ODP Leg 188 drilled through the upper portion of the Prydz Channel trough mouth fan at Site 1167, revealing evidence of repeated advances of the Lambert Glacier across the Prydz Bay shelf until the middle Pleistocene (Passchier et al. 2003, O'Brien et al. 2004). The Pagodroma Group occurs 200-500 km landward of Prydz Bay and consists of massive diamicts and boulder gravels deposited in an ice proximal environment near a grounding-line, and stratified facies representing more distal iceberg deposition. The depositional environments are considered to be analogous to the modern fjords of East Greenland with fast flowing polythermal tidewater glaciers (Hambrey \& McKelvey 2000a). The formations have ages ranging from early Miocene (or possibly Oligocene) to Pliocene-Pleistocene (Hambrey \& McKelvey 2000a, Whitehead et al. 2003) and indicate periods of significant glacial retreat (Hambrey \& McKelvey 2000b, Passchier \& Whitehead 2006, Whitehead et al. 2006).

Studies combining results from ODP Site 1165 off Prydz Bay and seismic data show that changes in margin architecture at c. $3 \mathrm{Ma}$ are related to changes in glacial thermal regime (Rebesco et al. 2006, Passchier 2007). Indeed, stable isotope studies (Hodell \& Venz 1992), and interpretations of siliceous microfossils (Bohaty \& Harwood 1998, Whitehead et al. 2005) indicate low sea ice concentrations and relatively high sea surface temperatures in the early Pliocene with a cooling trend occurring from the middle Pliocene onward. Previously, based on results from ODP Site 745 in the East Kerguelen sediment drift, Joseph et al. (2002) had argued that a stable East Antarctic Ice Sheet had established itself during the middle Pliocene. However, they also found that enhanced sediment accumulation from a less stable, wet-based, East Antarctic glacial source occurred periodically as short-term events 606 until the middle Pleistocene (Joseph et al. 2002).

The combined studies of ODP cores and field studies of the Pagodroma Group provide evidence of major shifts in the position of the grounding-line of the Lambert Glacier through the Late Neogene. Numerical modelling studies of erosion and sediment supply suggest that, besides climate, continued excavation and overdeepening of the glacial trough during ice advance phases is an important factor controlling the dynamics of the Lambert Glacier in the late Pleistocene (Taylor et al. 2004, O'Brien et al. 2007). Complete deglaciation as proposed in the dynamic ice sheet hypothesis has not been demonstrated in any of the datasets, and recent PRISM ice sheet reconstructions show the East Antarctic interior remaining ice covered (Hill et al. 2007). However the modelling does show significant ice loss at the margins, consistent with the retreat of fast flowing outlet glaciers associated with recognizable changes in sea level at continental margins elsewhere. Recent studies with coupled ocean-atmosphere general circulation models also re-emphasize the role of Antarctic terrestrial ice cover and sea ice extent during periods of warming and the need to improve our knowledge about Neogene ice configurations (Haywood \& Valdes 2004).

\section{Synchroneity of late deglacial ice retreat from widely separated areas of Antarctica's continental margin}

The nature and timing of the last large-scale, rapid warming event in Antarctica is an especially interesting target for scientific research given projections of significant warming in the centuries ahead (IPCC 2007). The retreat of Antarctica's ice sheet following the last glacial maximum (LGM) has been studied for more than 30 years via marine geology and continental glacial geomorphology (Anderson 1999, Anderson et al. 2002, Domack et al. 2006, and many others), and yet many questions remain regarding the timing, speed, and style of ice retreat. These questions are directly applicable to projections of climate and ice sheet behaviour into the future. How fast can Antarctica's ice sheet retreat during periods of warming (particularly as future warming may be greater than at any period since the Pliocene)? Is the style of past retreat suggestive of constant and steady sea level rise or do we see evidence of abrupt short-lived yet rapid intervals of ice retreat? How much did Antarctic glacial ice melting contribute to the global ocean meltwater pulses of the last deglaciation?

Antarctic marine geologists have recently collected expanded Holocene sedimentary sections from continental shelf basins by drilling and ultra-long piston coring (Crosta et al. 2005, Leventer et al. 2006, Anderson et al. 2006). By dating the biogenic sediments (indicative of marine productivity) or other open marine sediments immediately overlying the LGM diamict, it is possible to estimate the timing of ice retreat from outer and mid-shelf regions 
Table I. Radiocarbon-based estimates of the date of onset of the most recent rapid deglacial ice retreat from shelf basins in East and West Antarctica.

\begin{tabular}{|c|c|c|c|c|}
\hline Location & Core/sample & Water depth & ${ }^{14} \mathrm{C}$ age (yrs BP) & ${ }^{14} \mathrm{C}$ calendar age $(\mathrm{yrs} \mathrm{BP})^{\S}$ \\
\hline East Antarctic Margin $\left(68^{\circ} 45.1^{\prime} \mathrm{S}, 76^{\circ} 42.1^{\prime} \mathrm{E}\right)$ & JPC-25 & $848 \mathrm{~m}$ & $10625 \pm 35^{\mathrm{b}}$ & $10548 \pm 273$ \\
\hline East Antarctic Margin $\left(67^{\circ} 30^{\prime} \mathrm{S}, 65^{\circ} \mathrm{E}\right)$ & multiple cores & $400-500 \mathrm{~m}$ & $11000^{\mathrm{d}}$ & $11000 \pm 200$ \\
\hline West Antarctic Penin. $\left(64^{\circ} 51.7^{\prime} \mathrm{S}, 64^{\circ} 12.5^{\prime} \mathrm{W}\right)$ & ODP site 1098 & $1011 \mathrm{~m}$ & $11700 \pm 75^{\mathrm{e}}$ & $11510 \pm 300$ \\
\hline Western Ross Sea-Coulman area $\left(74^{\circ} \mathrm{S}, 172^{\circ} \mathrm{E}\right)$ & Multiple cores & $400-900 \mathrm{~m}$ & $11000^{f}$ & $\sim 11000 \pm 400$ \\
\hline
\end{tabular}

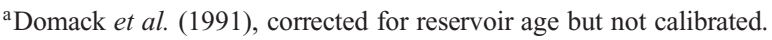

${ }^{b}$ Leventer et al. (2006), scaphapod carbonate, uncorrected ${ }^{14} \mathrm{C}$ age.

${ }^{\mathrm{c}}$ Stickley et al. (2005), acidified organic matter, uncorrected ${ }^{14} \mathrm{C}$ age.

${ }^{\mathrm{d}}$ Harris \& O'Brien (1998), Sedwick et al. $(1998,2001)$, corrected for reservoir age but not calibrated.

e Domack et al. (2001), Dunbar et al. (2002), interpolated age of base of laminated biogenic unit.

${ }^{\mathrm{f}}$ Domack et al. (1989), based on many cores, corrected for surface ages.

${ }^{g}$ Calibrated calendar year ages are derived through calibration using CALIB 4.2 and 5.0 (Stuiver et al. 2005).

${ }^{\S}$ Reservoir ages for the ODP 1098 were accomplished using the variable reservoir ages of van Beek et al. (2002).

(Licht et al. 1996, Leventer et al. 2006). At present there are still relatively few dates from these kinds of deposits and in fact there has been much focus in the literature on establishing the timing and extent of maximum ice advance during the LGM and the general character of deglaciation (e.g. Anderson et al. 2002) rather than the nature of discrete periods of rapid ice retreat.

Radiocarbon dating of Antarctic marine sediments is plagued by a variety of difficulties, including variable water column carbon reservoir ages and sedimentary reworking that results in the mixing of older and younger materials (Domack et al. 1989, Berkman \& Forman 1996, van Beek et al. 2002). However, independent estimates of reservoir age corrections are becoming available (Van Beek et al. 2002) as are palaeomagnetic intensity age determinations for the deglacial interval (Brachfeld et al. 2003) that serve to improve our ability to estimate the timing of key events on the Antarctic shelf during deglaciation. For example, Table I shows age estimates for the most recent onset of rapid deglacial ice retreat from Prydz Bay, the Ross Sea, Mac.Robertson Land, and the western shelf of the Antarctic Peninsula. To this list we add a palaeomagnetic age estimate of $10700 \pm 500$ yrs BP for the conclusion of the transition from grounded ice to a floating Larsen Ice Shelf $\left(64^{\circ} 47.1^{\prime} \mathrm{S}, 60^{\circ} 21.5^{\prime} \mathrm{W}, 901 \mathrm{~m}\right.$ water depth; Brachfeld et al. 2003).

The developing view is one of the onset of rapid and synchronous retreat of ice from widely separated regions of Antarctica's continental shelf beginning at $\sim 11500$ calendar years BP and lasting for up to $\sim 1000$ years. This apparent synchroneity is unexpected, given previous inferences of large geographic asynchroneity in the timing of maximum glacial advance and subsequent early deglacial history along Antarctica's margin (Anderson et al. 2002). However, a rapid retreat of ice from widespread regions of Antarctica's continental shelf beginning about 11500 years ago is not necessarily inconsistent with observations of asynchroneity earlier during the last deglaciation. A threshold may have been crossed, such as sea level or temperature rise, which forced a continent-wide response. The significance of this rapid retreat event is threefold.

1) It suggests that a global or hemispheric forcing agent was responsible for rapid loss of ice rather than regionally variable fluctuations in local energy balance or the dynamics of ice and ice streams interacting with bedrock and the ocean.

2) The timing coincides with estimates for the initiation of global meltwater pulse 1B (taken as 11500 to 11000 calendar years BP, after Fairbanks 1989), allowing for the possibility that loss of Antarctic ice contributed significantly to this event rather than accepting that virtually all meltwater came from the Northern Hemisphere ice sheets.

3) Synchroneity implies the sudden release of large volumes of freshwater into the Southern Ocean, raising the possibility of significant oceanic stratification and concomitant changes in productivity, nutrient fluxes, and the control of atmospheric $\mathrm{CO}_{2}$ levels by the Southern Ocean.

\section{Subglacial processes and flow dynamics of former Antarctic ice streams from marine geology and geophysics}

Recent marine geophysical and geological research from the Antarctic continental shelf has resulted in significant advances to our understanding of the extent, timing and dynamic behaviour of the West Antarctic Ice Sheet and the Antarctic Peninsula Ice Sheet during the last glacial maximum, as well as the processes and conditions at the former ice sheet bed. This research indicates extensive ice sheets in West Antarctica and the Antarctic Peninsula at the last glacial maximum. The ice sheet was positioned at, or close to, the shelf edge around the Peninsula, and in the Bellingshausen Sea and Pine Island Bay (Anderson et al. 2002, Ó Cofaigh et al. 2002, 2005a, Lowe \& Anderson 768 769 769
770 

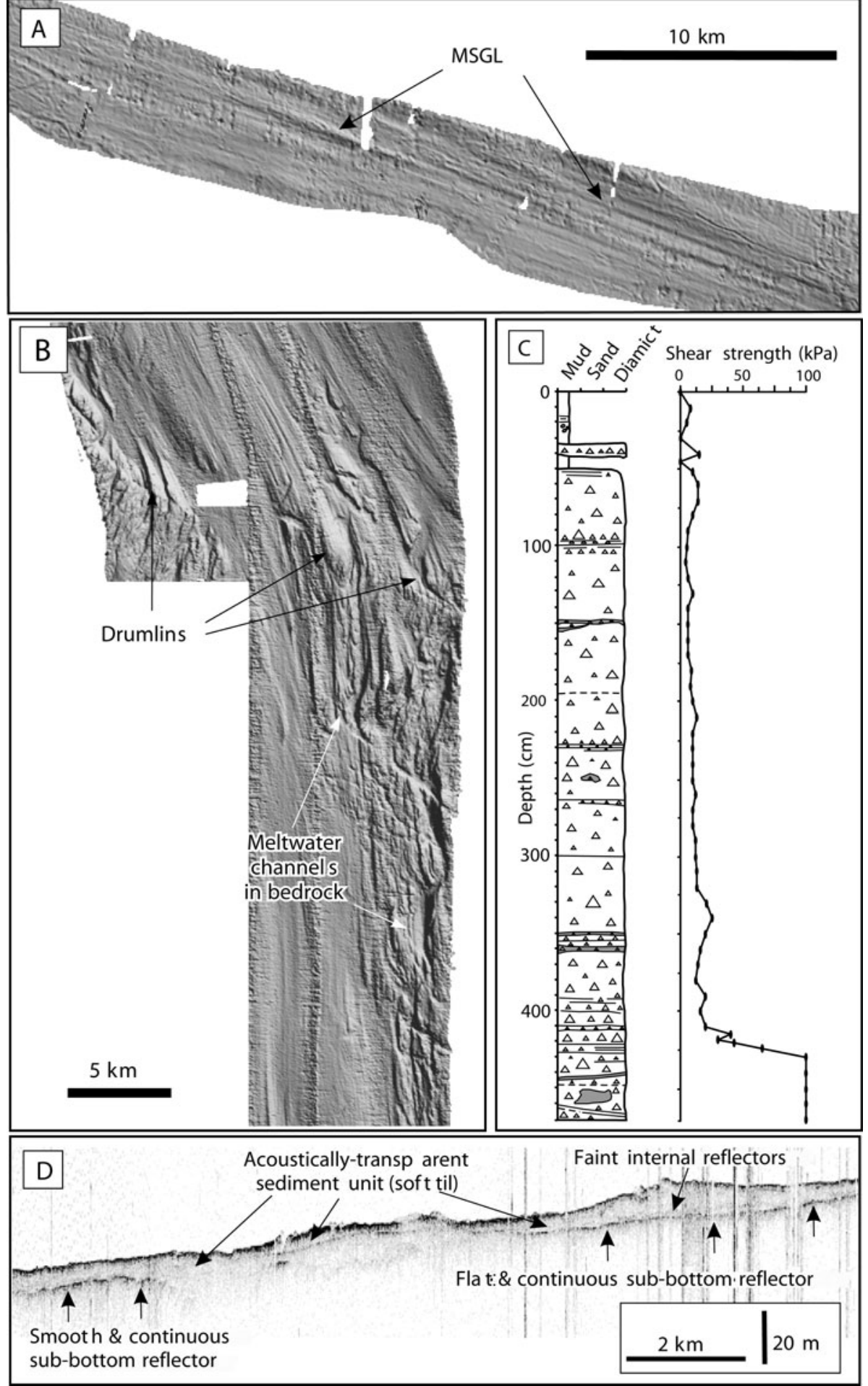

Fig. 5. Representative geophysical and geological records of palaeo-ice stream flow and deposition from bathymetric troughs on the Antarctic continental shelf. a. Swath bathymetry shaded relief image of mega-scale glacial lineations formed in sediment at the mouth of the Ronne Entrance, Bellingshausen Sea.

b. Swath bathymetry showing sea-floor morphology as a shaded relief image in middle-outer Marguerite Trough,

Antarctic Peninsula. Note subglacial meltwater channels and bedrock drumlins. The drumlins become highly attenuated downflow and evolve into sedimentary lineations. c. Core log and shear strength plot of sub-ice stream sediments, Marguerite Trough. Note the low shear strength massive till underlain by high shear strength $(>98 \mathrm{kPa})$ (stiff) till. d. TOPAS sub-bottom profiler record from the Ronne Entrance showing acoustically transparent sediment unit (soft till) sitting above a prominent basal reflector (arrowed). This profile is located perpendicular to the former direction of ice flow. Modified from Ó Cofaigh et al. (2005a, 2005b).
2002, Heroy \& Anderson 2005, Evans et al. 2006). In these areas large glacial troughs extend across the continental shelf, and sedimentary and geomorphic evidence from these troughs indicates that they were occupied by grounded palaeo-ice streams during, or immediately following, the last glacial maximum (e.g. Canals et al. 2000, 2002, Wellner et al. 2001, Camerlenghi et al. 2001, Lowe \&
Anderson 2002, Gilbert et al. 2003). This evidence includes elongate subglacial bedforms such as drumlins and mega-scale glacial lineations orientated along trough long axes (Fig. 5a \& b).

Mega-scale glacial lineations can attain lengths of greater than $20 \mathrm{~km}$ within the troughs and are characteristically formed in a weak $(0-20 \mathrm{kPa})$ porous and deformable till

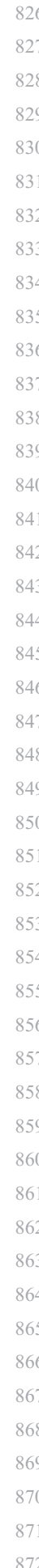


layer (Fig. 5c \& d) (Wellner et al. 2001, Shipp et al. 2002, Ó Cofaigh et al. 2002, 2005b, 2007, Dowdeswell et al. 2004, Evans et al. 2005, Hillenbrand et al. 2005). Such weak tills have been identified and mapped in all the palaeo-ice stream troughs investigated to date. They tend to be confined to the troughs and are not widely observed in the inter-trough areas. The association of this weak porous till layer with highly elongate subglacial bedforms implies that the rapid motion of these ice streams was facilitated, at least in part, by subglacial deformation of the soft bed. Geophysical data also indicate significant transport of subglacial till towards former ice stream termini (Ó Cofaigh et al. 2007).

Subglacial geology exerted a major control on ice stream development. A transition from crystalline bedrock to a sedimentary substrate within these troughs characteristically marks the onset of streaming flow. However, in Marguerite Trough (the cross-shelf bathymetric trough emanating from Marguerite Bay on the west side of the Antarctic Peninsula), streaming flow appears to have commenced over the crystalline bedrock by enhanced basal sliding, with the highest flow velocities occurring over the sedimentary substrate further downflow by, at least in part, subglacial deformation. This indicates spatial variation in the mechanism of rapid flow beneath individual ice streams. Subglacial meltwater channels eroded into crystalline bedrock in Pine Island Bay and Marguerite Bay (Ó Cofaigh et al. 2002, 2005b, Lowe \& Anderson 2003) demonstrate the development of organised drainage systems and the evacuation of meltwater beneath these ice streams. In the case of Mertz Trough in East Antarctica, McMullen et al. (2006) show that meltwater evacuation occurred during deglaciation.

A variety of glacial geomorphic features imaged on geophysical records and supplemented by investigations of core sedimentology indicate that the rate of ice stream retreat varied between different bathymetric troughs. For example, in Marguerite Trough subglacial till is overlain by a thin unit of (de)glacial sediment, and pristine mega-scale glacial lineations recording former streaming flow along the trough are not overprinted by moraines (Fig. 5). This suggests that during deglaciation, the Marguerite Trough ice stream underwent rapid floatation and collapse across much of its bed (Ó Cofaigh et al. 2005b), and it contrasts with slower ice stream recession in the Larsen-A region (Evans et al. 2005), the Bellingshausen (Ó Cofaigh et al. 2005a) and Ross seas (Shipp et al. 2002, Mosola \& Anderson 2006), and in Mertz Trough on the Wilkes Land continental margin (McMullen et al. 2006). This implies marked variations in the response of Antarctic palaeo-ice streams to climate warming during regional deglaciation and demonstrates that retreat of marine-based ice sheets is not necessarily uniformly rapid even in areas of reverse bed slope. This appears sensible given satellite observations of ice surface changes at the margins of
Antarctic ice streams are noticeably different (Davis et al. 2005). Such variability may be due to differences in oceantemperature at the ice-water interface across the ice sheet margin (e.g. Payne et al. 2004).

\section{Summary and future activities}

Analysis of geological evidence, often in conjunction with numerical modelling studies, has over the past few years generated substantial insights into the Cenozoic history of the Antarctic ice sheet and climate.

The traditional explanation for the genesis of ice in Antarctica related the tectonic opening of the Drake Passage with the development of the Antarctic Circumpolar Current and the isolation of Antarctic climate. Numerical modelling suggests, however, that while the timing of this first ice sheet, at around 34 million years, is likely to have been connected with a combination of the onset of the circumpolar current and orbital forcing, ice sheet formation was an inevitable consequence of declining atmospheric $\mathrm{CO}_{2}$ concentrations (and associated global cooling) that occurred throughout most of Cenozoic time.

A significant achievement, from drilling at the Antarctic margin off Cape Roberts, has been to show the cyclic expansion and contraction of the Antarctic ice sheet from its inception at $34 \mathrm{Ma}$ almost to the middle Miocene transition, with sea level varying on a scale of tens of metres. This might have been suspected from Milankovitch frequency patterns in the $\delta^{18} \mathrm{O}$ deep sea isotope record, but it could not be demonstrated until drill sites were so sited as to record not only the changes in sea level but also the advance and retreat of the ice edge.

The behaviour of the ice sheet since the middle Miocene is less clear, though fragmentary evidence from ancient landscapes and selective erosion by outlet glaciers, support the view of an East Antarctic ice sheet from around $14 \mathrm{Ma}$ with a persistent cold core and considerable fluctuations at the margin. Crucial new data for improving the chronology of climatic events, and providing a better record of their character will be collected from the Antarctic margin in the McMurdo region during the current phase of ANDRILL (Naish et al. 2006, Harwood et al. 2006).

During the Late Pliocene and throughout the Pleistocene, the Antarctic ice sheet may have been subject to less intense changes. Nonetheless, geological records still reflect modifications in ice volume, for example, since the LGM. Sedimentary cores across the Antarctic continental shelf show an unusual synchronous retreat at around 11500 calendar years BP, which could be associated with a global meltwater pulse at this time. Thus, the decay of ice from an LGM condition to its present-day form may have had worldwide rapid sea level and ocean chemistry consequences.

Whereas geological records inform us about the size and shape of the past ice sheets in Antarctica, they can also instruct us about the dynamic processes controlling ice

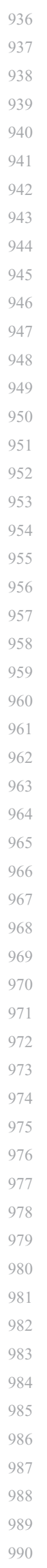


sheet form and flow. For example, investigations of sea floor morphology using swath bathymetry allow glacial geologists to map the beds of former ice streams and provide information on the controls on ice stream dynamics and subglacial landform development. Such information is particularly important in the assessment of modern ice streams as their bed morphology is difficult to comprehend beneath $1-2 \mathrm{~km}$ of ice.

Although our appreciation of Antarctic history has improved dramatically over the past decade, there is still much to learn. Significant questions exist, for example, on the evolution of Antarctic landscape both above and below the ice cover and its connection with ice sheet development, on past and present large-scale ice sheet dynamics and stability, on the role of sub-glacial water in the ice sheet system and on the influence of ice sheet evolution on Antarctic biology.

In 2004 the Scientific Committee on Antarctic Research (SCAR) recognized the importance of understanding past changes in Antarctica with the establishment of its Antarctic Climate Evolution (ACE) scientific research programme. This programme, in conjunction with the other SCAR research programmes (SALE - Subglacial Antarctic Lake Environments, AGCS - Antarctica in the Global Climate System, and EBA - Evolution and Biodiversity in Antarctica), aims to further integrate numerical models with geological data in order to understand the processes responsible for the growth and decay of large ice sheets and to comprehend the global significance of such changes.

\section{Acknowledgements}

At the recent SCAR meeting in Hobart, each of the scientific research programmes were asked to compile a paper detailing five recent findings in their area of investigation. This paper represents the first of such reviews. We thank the committee and members of the ACE programme for helpful input and advice. Further information on ACE can be found at www. ace.scar.org.

\section{References}

Anderson, J.B. 1999. Antarctic marine geology. Cambridge: Cambridge University Press, 297 pp.

Anderson, J.B., Shipp, S.S., Lowe, A.L., Wellner, J.S. \& Mosola, A.B. 2002. The Antarctic ice sheet during the last glacial maximum and its subsequent retreat history: a review. Quaternary Science Reviews, 21, $49-70$.

Anderson, J.B., Wellner, J.S., Bohaty, S., Manley, P.L. \& Wise JR, S.W. 2006. Antarctic Shallow Drilling Project provides key core samples, Eos Transactions $A G U, \mathbf{8 7}, 402$.

Barker, P.F. \& Burrell, J. 1977. The opening of Drake Passage. Marine Geology, 25, 15-34.

BARRETT, P.J. 1996. Antarctic palaeoenvironment through Cenozoic times - a review. Terra Antartica, 3, 103-119.

Barrett, P.J. In press. Cenozoic climate and sea level history from glacimarine strata off the Victoria Land coast, Cape Roberts Project,
Antarctica. In Hambrey, M.J., Christoffersen, P., Glasser, N.F. \& Hubbard, B., eds. Glacial Processes and Products. International Association of Sedimentologists, Special Publication.

BART, P.J., DE BATIST, M. \& JOKAT, W. 1999. Interglacial collapse of Crary Trough Mouth fan, Weddell Sea, Antarctica; implications for Antarctic glacial history. Journal of Sedimentary Research, 69, 1276-1289.

Bart, P.J., Anderson, J.B., Trincardi, F. \& Shipp, S.S. 2000. Seismic data from the northern basin, Ross Sea, record extreme expansions of the East Antarctic Ice Sheet during the late Neogene. Marine Geology, 166, 31-50.

Berkman, P.A. \& Forman, S.L. 1996. Pre-bomb radiocarbon and the reservoir correction for calcareous marine species in the Southern Ocean. Geophysical Research Letters, 23, 363-366.

Billups, K., Pälike, H., Channell, J.E.T., Zachos, J.C. \& Shackleton, N.J. 2004. Astronomic calibration of the late Oligocene through early Miocene geomagnetic polarity time scale. Earth and Planetary Science Letters, 224, 33-44.

Bонату, S.M. \& Harwood, D.M. 1998. Southern Ocean paleotemperature variation from high-resolution silicoflagellate biostratigraphy. Marine Micropaleontology, 33, 241-272.

Brachfeld, S., Domack, E., Kissel, C., Laj, C., Leventer, A., Ishman, S., Gilbert, R., Camerlenghi, A. \& Eglington, L.B. 2003. Holocene history of the Larsen-A Ice Shelf constrained by geomagnetic paleointensity dating. Geology, 31, 749-752.

Camerlenghi, A., Domack, E., Rebesco, M., Gilbert, R., Ishman, S., Leventer, A., Brachfield, S. \& Drake, A. 2001. Glacial morphology and post-glacial contourites in northern Prince Gustav Channel (NW Weddell Sea, Antarctica). Marine Geophysical Research, 22, 417-443.

Canals, M., Urgeles, R. \& Calafat, A.M. 2000. Deep sea-floor evidence of past ice streams off the Antarctic Peninsula. Geology, 28, 31-34.

Canals, M., Casamor, J.L., Urgeles, R., Calafat, A.M., Domack, E.W., Baraza, J., Farran, M. \& De Batist, M. 2002. Seafloor evidence of a subglacial sedimentary system off the northern Antarctic Peninsula Geology, 30, 603-606.

Coxall, H.K., Wilson, P.A., Pälike, H., Lear, C. \& Backman, J. 2005. Rapid stepwise onset of Antarctic glaciation and deeper calcite compensation in the Pacific Ocean. Nature, 433, 53-57.

Crosta, X., Crespin, J., Billy, I. \& Ther, O. 2005. Major factors controlling Holocene $\delta^{13} \mathrm{C}_{\text {org }}$ change in a seasonal sea-ice environment, Adélie Land, East Antarctica. Global Biogeochemical Cycles, 19, doi:10.1029/ 2004GB002426.

Crowley, T.J. \& Kim, K.-Y. 1995. Comparison of longterm greenhouse projections with the geologic record. Geophysical Research Letters, 22, 933-936.

Davis, K., Yonghong, L., McConnell, J.R., Frey, M.M. \& Hanna, E. 2005. Snowfall-driven growth in East Antarctic Ice Sheet mitigates recent sealevel rise. Science, 308, 1898-1901.

DeConto, R.M. \& Pollard, D. 2003a. A coupled climate-ice sheet modeling approach to the early Cenozoic history of the Antarctic ice sheet. Palaeogeography Palaeoclimatology Palaeoecology, 198, 39-53.

DeConto, R.M. \& Pollard, D. 2003b. Rapid Cenozoic glaciation of Antarctica induced by declining atmospheric $\mathrm{CO}_{2}$. Nature, 421, 245-249.

DeConto, R.M., Pollard, D. \& Harwood, D. 2007. Sea ice feedback and Cenozoic evolution of Antarctic climate and ice sheets. Paleoceanography, 22, art. no. PA3214.

Denton, G.H., Prentice, M.L., Kellogg, D.E. \& Kellogg, T.B. 1984. Late Tertiary history of the Antarctic ice sheet: evidence from the Dry Valleys. Geology, 12, 263-267.

Domack, E.W., Jull, A.J.T. \& Donahue, D.J. 1991. Holocene chronology for the unconsolidated sediments at Hole 740 A; Prydz Bay, East Antarctica. In Barron, J., Larsen, B. \& Shipboard Scientific Party. Kerguelen Plateau-Pydz Bay. Proceedings of the Ocean Drilling Program, Scientific Results, 119, 747-750.

Domack, E.W., Jull, A.J.T., Anderson, J.B., Linick, T.W. \& Williams, C.R. 1989. Application of tandem accelerator mass-spectrometer dating to Late Pleistocene-Holocene sediments of the East Antarctic continental shelf. Quaternary Research, 31, 277-287. 
1101 Domack, E., Leventer, A., Dunbar, R., Taylor, F., Brachfeld, S., Sunnneskog, C. \& ODP Leg 178 Scientific Party. 2001. Chronology of the Palmer Deep site, Antarctic Peninsula: a Holocene palaeoenvironmental reference for the circum-Antarctic. The Holocene, 11, 1-9.

Domack, E., Amblas, D., Gilbert, R., Brachfeld, S., Camerlenghi, A., Rebesco, M., Canals, M. \& Urgeles, R. 2006. Subglacial morphology and glacial evolution of the Palmer Deep outlet system, Antarctic Peninsula. Geomorphology, 75, 125-142.

Dowdeswell, J.A., Ó Cofaigh, C. \& Pudsey, C.J. 2004. Thickness and extent of the subglacial till layer beneath an Antarctic paleo-ice stream. Geology, 32, 13-16.

1110 Dunbar, G.B., Naish, T.R., Barrett, P.J., Fielding, C.F. \& Powell, R.D. In

press. Constraining the amplitude of late Oligocene bathymetric changes in western Ross Sea during orbitally-induced oscillations in the East Antarctic Ice Sheet: (1) Implications for glacimarine sequence stratigraphic model. Palaeoclimatology, Palaeogeography, Palaeoecology.

Dunbar, R.B., Ravelo, A.C., Domack, E. \& Leventer, A. 2002. Decadal-tomillennial oceanographic variability along the Antarctic Peninsula: ODP Site 1098 demonstrates strong solar forcing signals in the Southern Ocean. Eos Transactions $A G U, \mathbf{8 3}$, Fall Meeting Suppl., abstract PP22B-10.

Eldrett, J.S., Harding, I.C., Wilson, P.A., Butler, E. \& Roberts, A.P. 2007. Continental ice in Greenland during the Eocene and Oligocene. Nature, 446, 176-179.

EPICA Community Members. 2004. Eight glacial cycles from an Antarctic ice core. Nature, 429, 623-628.

Evans, J., Dowdeswell, J.A., Ó Cofaigh, C., Benham, T.J. \& Anderson, J.B. 2006. Extent and dynamics of the West Antarctic Ice Sheet on the outer continental shelf of Pine Island Bay during the last glaciation. Marine Geology, 230, 53-72.

Evans, J., Pudsey, C.J., Ó Cofaigh, C., Morris, P. \& Domack, E. 2005. Late Quaternary glacial history, flow dynamics and sedimentation along the eastern margin of the Antarctic Peninsula Ice Sheet. Quaternary Science Reviews, 24, 741-774.

Exon, N., Kennett, J., Malone, M., Brinkhuis, H., Chaproniere, G., Ennyu, A., Fothergill, P., Fuller, M., Grauer, M., Hill, P., Janecek, T., Kelly, C., Latimer, J., McGonigal, K., Nees, S., Ninnemann, U., Nuernberg, D., Pekar, S., Pellaton, C., Pfuhl, H., Robert, C., Röhl, U., Schellenberg, S., Shevenell, A., Stickley, C., Suzuki, N., Touchard, Y., Wei, W. \& WhiтE, T. 2002. Drilling reveals climatic consequences of Tasmanian Gateway opening. Eos, Transactions AGU, 83, 253, 258-259.

FairbanKs, R.G. 1989. A 17,000-year glacio-eustatic sea level record: influence of glacial melting rates on the Younger Dryas event and deepocean circulation. Nature, 342, 637-642.

Gilbert, R., Domack, E.W. \& Camerlenghi, A. 2003. Deglacial history of the Greenpeace Trough: ice sheet to ice shelf transition in the northern Weddell Sea. Antarctic Research Series, 79, 195-204.

Hambrey, M.J. \& McKelvey, B.C. 2000a. Neogene fjordal sedimentation on the western margin of the Lambert Graben, East Antarctica. Sedimentology, 47, 577-608.

Hambrey, M.J. \& McKelvey, B.C. 2000b. Major Neogene fluctuations of the East Antarctic ice sheet: stratigraphic evidence from the Lambert Glacier region. Geology, 28, 865-960.

HARRIS, P.T. \& O'Brien, P.E. 1998. Bottom currents, sedimentation and icesheet retreat facies successions on the Mac. Robertson shelf, East Antarctica. Marine Geology, 151, 47-72.

Harwood, D.M., Florindo, F., Levy, R.H., Fielding, C.R., Pekar, S.F., Speece, M.A. \& SMS Science Team. 2006. Southern McMurdo Sound Prospectus, ANDRILL Contribution No. 5. Lincoln, NE: UNL, 32 pp. (www.andrill.org)

Haywood, A.M. \& Valdes, P.J. 2004. Modelling Pliocene warmth: contribution of atmosphere, oceans and cryosphere. Earth and Planetary Science Letters, 218, 363-377.

Heroy, D. \& Anderson, J.B. 2005. Ice-sheet extent of the Antarctic Peninsula region during the Last Glacial Maximum (LGM) - insights from glacial geomorphology. Geological Society of America Bulletin, 117, $1497-1512$
Hicock, S.R., BarRett, P.J. \& Holme, P.J. 2003. Fragment of an ancient outlet glacier system near the top of the Transantarctic Mountains. Geology, 31, 821-824.

Hill, D.J., Haywood, A.M., Hindmarsh, R.C.A. \& Valdes, P.J. 2007. Characterising ice sheets during the mid Pliocene: evidence from data and models, In Williams, M., Haywood, A.M., Gregory, J. \& Schmidt, D., eds. Deep-time perspectives on climate change: marrying the signal from computer models and biological proxies. The Micropalaeontological Society Special Publications. The Geological Society of London.

Hillenbrand, C.-D., Baesler, A. \& Grobe, H. 2005. The sedimentary record of the last glaciation in the western Bellingshausen Sea (West Antarctica) implications for the interpretation of diamictons in a polar-marine setting. Marine Geology, 216, 191-204.

Hodell, D.A. \& Venz, K. 1992. Toward a high-resolution stable isotope record of the Southern Ocean during the Pliocene-Pleistocene (4.8 to $0.8 \mathrm{Ma})$. Antarctic Research Series, 56, 265-310.

Holbourn, A., Kuhnt, W., Schulz, M. \& Erlrnkeuser, H. 2005. Impacts of orbital forcing and atmospheric carbon dioxide on Miocene ice-sheet expansion. Nature, 438, 483-487.

Huber, M., Brinkhuis, H., Stickley, C.E., Doos, K., Sluijs, A., WarnaAr, J., Williams, G.L. \& Schellenberg, S.A. 2004. Eocene circulation of the Southern Ocean: was Antarctica kept warm by subtropical waters? Paleoceanography, 19, doi:10.1029/2004PA001014.

IPCC. 2001. Climate change 2001: the scientific basis. In Houghton, J.T., Ding, Y., Griggs, D.J., Noguer, M., van der Linden, P.J., Dai, X., Maskell, K. \& Johnson, C.A., eds. Contribution of Working Group I to the Third Assessment Report of the Intergovernmental Panel on Climate Change. Cambridge: Cambridge University Press, 944 pp.

IPCC. 2007. Climate change 2007 - the physical science basis. In Contribution of Working Group I to the Fourth Assessment Report of the IPCC. Cambridge: Cambridge University Press, 1009 pp.

JeZeK, K.C. 2003. Observing the Antarctic ice sheet using the RADARSAT-1 synthetic aperture radar. Polar Geography, 27, 197-209.

Joseph, L.H., Rea, D.K., van der Pluijm, B.A. \& Gleason, J.D. 2002. Antarctic environmental variability since the late Miocene: ODP Site 745 , the East Kerguelen sediment drift. Earth and Planetary Science Letters, 201, 127-142.

KenNetT, J.P. 1977. Cenozoic evolution of Antarctic glaciation, the circumAntarctic oceans and their impact on global paleoceanography. Journal of Geophysical Research, 82, 3843-3859.

Kennett, J.P. \& Shackleton, N.J. 1976. Oxygen isotopic evidence for the development of the psychryosphere 38 my ago. Nature, $\mathbf{2 6 0}$, $513-515$.

LawVer, L.A. \& Gahagan, L.M. 1998. Opening of Drake Passage and its impact on Cenozoic ocean circulation, In CROwLEY, T.J. \& BURKe, K.C., eds. Tectonic boundary conditions for climate reconstructions. Oxford Monographs on Geology and Geophysics, Vol. 39. New York: Oxford University Press, 212-223.

Le BrocQ, A. 2007. Validating models of the West Antarctic Ice Sheet. PhD thesis, University of Bristol. [Unpublished].

Lear, C.H., Rosenthal, Y., Coxall, H.K. \& Wilson, P.A. 2004. Late Eocene to early Miocene ice-sheet dynamics and the global carbon cycle. Paleoceanography, 19, doi:10.1029/2004PA001039.

Leventer, A., Domack, E., Dunbar, R., Pike, J., Stickley, C., Maddison, E., Brachfeld, S., Manley, P. \& McClennen, C. 2006. Marine sedimen record of the deglaciation of the East Antarctic Margin. GSA Today, 16, $4-10$.

Licht, K.J., Jennings, A.E., Andrews, J.T. \& Williams, K.M. 1996 Chronology of late Wisconsin ice retreat from the western Ross Sea, Antarctica. Geology, 24, 223-226.

Livermore, R., Eagles, G., Morris, P. \& Maldonado, A. 2004. Shackleton Fracture Zone: no barrier to early circumpolar ocean circulation. Geology, 32, 797-800.

Lowe, A.L. \& Anderson, J.B. 2002. Reconstruction of the West Antarctic ice sheet in Pine Island Bay during the Last Glacial Maximum 
and its subsequent retreat history. Quaternary Science Reviews, 21, 1879-1897.

Lowe, A.L. \& Anderson, J.B. 2003. Evidence for abundant subglacial meltwater beneath the paleo-ice sheet in Pine Island Bay, Antarctica. Journal of Glaciology, 49, 125-138.

Maslin, M.A., Li, Z., Loutre, M.-F. \& Berger, A. 1999. The contribution of orbital forcing to the progressive intensification of Northern Hemisphere glaciation. Quaternary Science Reviews, 17, 411-426.

McMullen, K., Domack, E.W., Leventer, A., Olson, C., Dunbar, R. \& BrachFIELD, S. 2006. Glacial morphology and sediment formation in the Mertz Trough, East Antarctica. Palaeogeography, Palaeoclimatology and Palaeoecology, 231, 169-180.

Mikolajewicz, U., Maier-Reimer, E., Crowley, T.J. \& Kim, K.-Y. 1993. Effect of Drake and Panamanian gateways on the circulation of an ocean model. Paleoceanography, 8, 409-426.

Mix, A.C. \& Ruddiman, W.F. 1984. Oxygen isotopes and Pleistocene ice volumes. Quaternary Research, 21, 1-20.

Mosola, A.B. \& Anderson, J.B. 2006. Expansion and rapid retreat of the West Antarctic Ice Sheet in the eastern Ross Sea: possible consequences of over-extended ice streams? Quaternary Science Reviews, 25, 2177-2196.

Naish, T.R., Levy, R.H., Powell, R.D. \& MIS Project Science and Operations Team Members. 2006. Scientific logistics implementation plan for the ANDRILL McMurdo Ice Shelf Project. ANDRILL Contribution 7. Lincoln, NE: UNL, 117 pp. (www.andrill.org)

Naish, T.R., Wilson, G.S., Dunbar, G.B. \& Barrett, P.J. In press. Constraining the amplitude of late Oligocene bathymetric changes in western Ross Sea during orbitally-induced oscillations in the East Antarctic Ice Sheet: (2) Implications for global glacio-eustasy. Palaeoclimatology, Palaeogeography, Palaeoecology.

Naish, T.R., Woolfe, K.J., Barrett, P.J., Wilson, G.S. \& 29 others. 2001a. Orbitally induced oscillations in the East Antarctic ice sheet at the Oligocene-Miocene boundary. Nature, 413, 719-723.

Naish, T.R., Barrett, P.J., Dunbar, G.B., Woolfe, K.J., Dunn, A.G., Henrys, S.A., Claps, M., Powell, R.D. \& Fielding, C.R. 2001 b. Sedimentary cyclicity in CRP drillcore, Victoria Land Basin, Antarctica. Terra Antartica, 8, 225-244.

Naish, T.R., Powell, R.D., Henrys, S., Wilson, G.S., Krissek, L.A., Niessen, F., Pompilio, M., Scherer, R., Talarico, F., Levy, R.H. \& Pyne, A. 2007. Late Neogene climate history of the Ross Embayment: initial results from the ANDRILL McMurdo Ice Shelf Project. In Cooper, A.K., Raymond, C.R. \& the ISAES team. Antarctica: a keystone in a changing world - online proceedings of the 10th ISAES, 10.3133/of2007-1047.

Nong, G.T., NajJar, R.G., Seidov, D. \& Peterson, W. 2000. Simulation of ocean temperature change due to the opening of Drake Passage. Geophysical Research Letters, 27, 2689-2692.

Ó Cofaigh, C., Evans, J., Dowdesell, J.A. \& Larter, R.D. 2007. Till characteristics, genesis and transport beneath Antarctic paleo-ice streams. Journal of Geophysical Research (Earth Surface), 112, art. No. F03006.

Ó Cofaigh, C., Dowdeswell, J.A., Allen, C.S.A., Hiemstra, J., Pudsey, C.J., Evans, J. \& Evans, D.J.A. 2005b, Flow dynamics and till genesis associated with a marine-based Antarctic palaeo-ice stream. Quaternary Science Reviews, 24, 709-740.

Ó Cofaigh, C., Pudsey, C.J., Dowdeswell, J.A. \& Morris, P. 2002, Evolution of subglacial bedforms along a paleo-ice stream, Antarctic Peninsula continental shelf. Geophysical Research Letters, 29, 10.1029/ 2001GL014488.

Ó Cofaigh, C., Larter, R.D., Dowdeswell, J.A., Hillenbrand, C.-D., Pudsey, C.J., Evans, J. \& Morris, P. 2005a. Flow of the West Antarctic Ice Sheet on the continental margin of the Bellingshausen Sea at the Last Glacial Maximum. Journal of Geophysical Research, 110, 10.1029/2005JB003619.

O’Brien, P.E \& Harris, P.T. 1996. Patterns of glacial erosion in Prydz Bay and the past behaviour of the Lambert Glacier. Papers and Proceedings of the Royal Society of Tasmania, 130, 79-85.
O’Brien, P.E., Cooper, A.K., Florindo, F., Handwerger, D., Lavelle, M., Passchier, S., Pospichal, J.J., Quilty, P.G., Richter, C., Theissen, K.M. \& Whitehead, J.M. 2004. Prydz Channel Fan and the history of extreme ice advances in Prydz Bay. Proceedings ODP Initial Reports, 188, 10.2873/odp.proc.sr.188.016.2004.

O’Brien, P.E., Goodwin, I., Forsberg, C.-F., Cooper, A.K. \& Whitehead, J. 2007. Late Neogene ice drainage changes in Prydz Bay, East Antarctica and the interaction of Antarctic ice sheet evolution and climate. Palaeogeography, Palaeoclimatology, Palaeoecology, 245, 390-410.

Pagani, M., Zachos, J.C., Freeman, K.H., Tipple, B. \& Bohaty, S.M. 2005. Marked decline in atmospheric carbon dioxide concentrations during the Paleogene. Science, 309, 600-603.

Passchier, S. 2001. Provenance of the Sirius Group and related Upper Cenozoic glacial deposits from the Transantarctic Mountains, Antarctica: relation to landscape evolution and ice-sheet drainage. Sedimentary Geology, 144, 263-290.

PAsschieR, S. 2004. Variability in geochemical provenance and weathering history of Sirius Group strata, Transantarctic Mountains: implications for Antarctic glacial history. Journal of Sedimentary Research, 74, 607-619.

PAsschier, S. 2007. East Antarctic ice-sheet dynamics between 5.2 and $0 \mathrm{Ma}$ from a high-resolution terrigenous particle size record, ODP Site 1165, Prydz Bay-Cooperation Sea. In Cooper, A.K., Raymond, C.R. \& the ISAES TEAM. Antarctica: a keystone in a changing world - online proceedings of the $10^{\text {th }}$ ISAES, 10.3133/of2007-1047.srp043.

Passchier, S. \& Whitehead, J.M. 2006. Anomalous geochemical provenance and weathering history of Plio-Pleistocene glaciomarine fjord strata, Bardin Bluffs Formation, East Antarctica. Sedimentology, 53, 929-942.

Passchier, S., O’Brien, P.E., Damuth, J.E., Januszczack, N., Handwerger, D.A. \& Whitehead, J.M. 2003. Pliocene-Pleistocene glaciomarine sedimentation in eastern Prydz Bay and development of the Prydz trough-mouth fan, ODP Sites 1166 and 1167, East Antarctica. Marine Geology, 199, 179-305.

Payne, A.J., Vieli, A., Shepherd, A., Wingham, D.J. \& Rignot, E. 2004. Recent dramatic thinning of largest West-Antarctic ice stream triggered by oceans. Geophysical Research Letters, 31, L23401.

PekAR, S.F. \& DeConto, R.M. 2006 High-resolution ice-volume estimates for the early Miocene: evidence for a dynamic ice sheet in Antarctica. Palaeogeography, Palaeoclimatology, Palaeoecology, 231, 101-109.

Pekar, S., DeConto, R.M. \& Harwood, D. 2006. Resolving a late Oligocene conundrum: deep sea warming and Antarctic glaciation. Palaeogeography Palaeoclimatology Palaeoecology, 231, 29-49.

Pollard, D. \& DeConto, R.M. 2005. Hysteresis in Cenozoic Antarctic Ice Sheet variations. Global and Planetary Change, 45, 9-21.

Pollard, D., DeConto, R.M. \& Nyblade, A. 2005. Sensitivity of Cenozoic Antarctic ice sheet variations to geothermal heat flux. Global and Planetary Change, 49, 63-74.

Rebesco, M., Camerlenghi, A., Geletti, R. \& Canals, M. 2006. Margin architecture reveals the transition to the modern Antarctic ice sheet ca. 3 Ma. Geology, 34, 301-304.

Ruddiman, W.F., Raymo, M.E., Martinson, D.G., Clement, B.M. \& BACKMAN, J. 1989. Mid-Pleistocene evolution of Northern Hemisphere climate. Paleoceanography, 4, 353-412.

SCHER, H.D. \& MARTIN, E.E. 2006. Timing and climatic consequences of the opening of Drake Passage. Science, 312, 428-430.

Sedwick, P.N., Harris, P.T., Robertson, L.G., McMurtry, G.M., Cremer, M.D. \& Robinson, P. 1998. A geochemical study of marine sediments from the Mac.Robertson shelf, East Antarctica: initial results and palaeoenvironmental implications. Annals of Glaciology, 27, 268-274.

Sedwick, P.N., Harris, P.T., Robertson, L.G., McMurtry, G.M., Cremer, M.D. \& Robinson, P. 2001. Holocene sediment records from the continental shelf of Mac.Robertson Land, East Antarctica. Paleoceanography, 16, 212-225.

Shackleton, N.J., Backman, J., Zimmerman, H., Kent, D.V., Hall, M.A., Roberts, D.G., Schnitker, D., Baldauf, J.G., Desprairies, A., Homrighausen, R., Huddlestun, P., Keene, J.B., Kaltenback, A.J., 
Krumsiek, K.A.O., Morton, A.C., Murray, J.W. \& Westberg-Smith, J. 1984. Oxygen isotope calibration of the onset of ice-rafting and history of glaciation in the North Atlantic region. Nature, 307, 620-623.

Shipp, S.S., Wellner, J.S. \& Anderson, J.B. 2002. Retreat signature of a polar ice stream: sub-glacial geomorphic features and sediments from the Ross Sea, Antarctica. In Dowdeswell, J.A. \& O Cofaigh, C., eds. Glacier-influenced sedimentation on high-latitude continental margins. Geological Society, London, Special Publication, 203, 277-304.

Siegert, M.J. \& Dowdeswell, J.A. 1996. Spatial variations in heat at the base of the Antarctic Ice Sheet from analysis of the thermal regime above subglacial lakes. Journal of Glaciology, 42, 501-509.

Siegert, M.J., Carter, S., Tabacco, I., Popov, S. \& Blankenship, D. 2005. A revised inventory of Antarctic subglacial lakes. Antarctic Science, 17, 453-460.

Stern, T.A., Baxter, A.K. \& Barrett, P.J. 2005. Isostatic rebound due to glacial erosion within the Transantarctic Mountains. Geology, 33, 221-224.

Stickley, C.E., Pike, J., Leventer, J., Dunbar, R., Domack, E.W., Brachfeld, S., Manley, P. \& McClennen, C. 2005. Deglacial ocean and climate seasonality in laminated diatom sediments. Mac.Robertson Shelf, Antarctica: Palaeogeography, Palaeoclimatology, Palaeoecology, 227, 290-310

Stickley, C.E., Brinkhuis, H., Schellenberg, S.A., Sluijs, A., Röhl, U., Fuller, M., Grauert, M., Huber, M., Warnaar, J. \& Williams, G.L. 2004. Timing and nature of the deepening of the Tasmanian Gateway. Paleoceanography, 19, 10.1029/2004PA001022.

Stuiver, M., Reimer, P.J. \& Reimer, R.W. 2005. CALIB 5.0.2., www program and documentation, http://www.calib.qub.ac.uk/.

Sugden, D.E. \& Denton, G.H. 2004. Cenozoic landscape evolution of the Convoy Range to Mackay Glacier area, Transantarctic Mountains: Onshore to offshore synthesis. Geological Society of American Bulletin, 116, 840-857.

Taylor, J., Siegert, M.J., Payne, A.J., Hambrey, M.J., O’Brien, P.E., Cooper, A.K. \& Leitchenkov, G. 2004. Topographic controls on postOligocene changes in ice-sheet dynamics, Prydz Bay region, East Antarctica. Geology, 32, 197-200.

Thorn, V. \& DeConto, R.M. 2006. Antarctic climate at the Eocene/ Oligocene boundary - climate model sensitivity to high latitude vegetation type and comparisons with the palaeobotanical record. Palaeogeography Palaeoclimatology Palaeoecology, 231, 134-157.
Toggweiler, J.R. \& BJornsson, H. 2000. Drake Passage and paleoclimate. Journal of Quaternary Science, 15, 319-328.

Tripati, A., Backman, J., Elderfield, H. \& Ferretti, P. 2005. Eocene bipolar glaciation associated with global carbon cycle changes. Nature, $\mathbf{4 3 6}$ $341-346$.

van Beek, P., Reyss, J.-L., Paterne, M., Gersonde, R., van der Loeff, M.R. \& KUHN, G. 2002. 226Ra in barite: absolute dating of Holocene Southern Ocean sediments and reconstruction of sea-surface reservoir ages. Geology, 30, 731-734.

Webb, P.N., Harwood, D.M., McKelvey, B.C., Mercer, J.H. \& Stott, L.D 1984. Cenozoic marine sedimentation and ice-volume variation on the East Antarctic craton. Geology, 12, 287-291.

Wellner, J.S., Lowe, A.L., Shipp, S.S. \& Anderson, J.B. 2001. Distribution of glacial geomorphic features on the Antarctic continental shelf and correlation with substrate: implications for ice behaviour. Journal of Glaciology, 47, 397-411.

WhiteHEad, J.M., Harwood, D.M. \& McMinn, A. 2003. Ice-distal upper Miocene marine strata from inland Antarctica. Sedimentology, 50, 531-552.

WhiteheAd, J.M., Wotherspoon, S. \& Bohaty, S.M. 2005. Minimal Antarctic sea ice during the Pliocene. Geology, 33, 137-140.

Whitehead, J.M., Ehrmann, W., Harwood, D.M., Hillenbrand, C.-D., Quilty, P.G., Hart, C., Taviani, M., Thorn, V. \& McMinn, A. 2006. Late Miocene paleoenvironment of the Lambert Graben embayment, East Antarctica, evident from: mollusc paleontology, sedimentology and geochemistry. Global and Planetary Change, 50, 127-147.

Wise, S.W. Jr, Breza, J.R., Harwood, D.M., Wei, W. \& Zachos, J. 1991 Paleogene glacial history of Antarctica. In McKenzie, J.A. \& Weissert, H., eds. Controversies in modern geology; evolution of geological theories in sedimentology, Earth history and tectonics. London: Academic Press, 133-171.

Zachos, J., BrezA, J. \& Wise, S.W. 1992. Early Oligocene ice-sheet expansion on Antarctica, sedimentological and isotopic evidence from Kerguelen Plateau. Geology, 20, 569-573.

Zachos, J.C., Flower, B.P. \& Paul, H. 1997. Orbitally paced climate oscillations across the Oligocene/Miocene boundary. Nature, $\mathbf{3 8 8}$, 567-570.

Zachos, J., Pagani, M., Sloan, L. \& Thomas, E. 2001. Trends, rhythms, and aberrations in global climate 65 Ma to present. Science, 292, 686-693. 